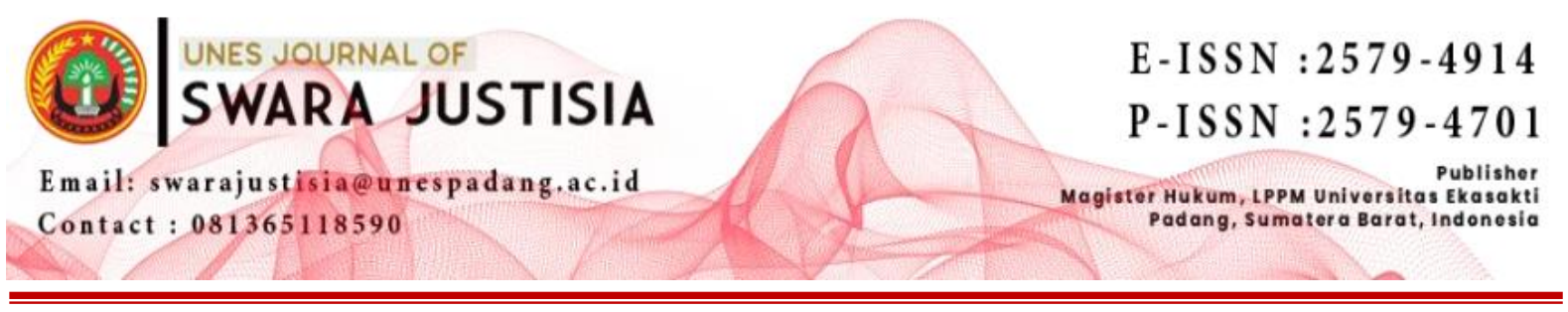

\title{
STRATEGI PENYIDIK MENGATASI KENDALA DALAM MENGUMPULKAN ALAT BUKTI TINDAK PIDANA PORNOGRAFI MELALUI MEDIA ELEKTRONIK
}

\author{
Dio Frananda \\ Program Magister Ilmu Hukum,Universitas Ekasakti, Padang, Indonesia \\ Email: diofrananda7@gmail.com
}

\begin{abstract}
Obstacles Faced by Investigators of the Kerinci Satreskrim Polres in Collecting Evidence of the Crime of Pornography Through Electronic are the lack of understanding and mastery of investigators in the field of information technology. There is too much workload for investigators in the cyber crime unit of the Kerinci Police Satreskrim. Investigators are not focused on dealing with cyber crime, especially pornography, their concentration is divided into other cases. The lack of modern facilities in the search for evidence is also an internal technical obstacle for the Kerinci Criminal Investigation Unit in collecting evidence of pornographic crimes. Second, the strategy of the Kerinci Satreskrim Investigator in Overcoming Obstacles in Collecting Evidence of Pornography Crimes Through Electronic is to carry out digital forensic examinations on digital goods that have memory as a place to store electronic data. Observations were made to determine the condition of electronic evidence (ON or OFF). Followed by whether the electronic evidence is connected to the network. In order to prevent the loss of evidence, digital evidence documentation is carried out by means of the initial position of the evidence, a photo must be taken. Initial photos are very useful for determining the type of data and information to be sought in electronic evidence. All actions in the confiscation process must be stated in the Minutes of confiscation. Investigators must pay attention not to let the perpetrators/suspects touch the electronic evidence after the investigators conduct a raid (one button can erase all digital evidence in the evidence).
\end{abstract}

Keywords: Investigation, Electronic Media, Pornography, Evidence

\begin{abstract}
ABSTRAK
Kendala Yang Dihadapi Penyidik Satreskrim Polres Kerinci Dalam Mengumpulkan Alat Bukti Tindak Pidana Pornografi Melalui Elektronik adalah kurangnya pemahaman dan penguasaan penyidik di bidang teknologi informasi, sebagian besar personil penyidik Satreskrim Polres Kerinci masih belum menguasai Teknologi Informasi. Terlalu banyaknya beban pekerjaan penyidik yang ada di unit cyber crime satreskrim polres kerinci. Penyidik tidak terfokus untuk menangani cyber crime khususnya Pornografi konsentrasi mereka terpecah kepada perkara-perkara lain. Kurangnya fasilitas yang modern dalam pencarian barang bukti juga menjadi kendala teknis internal Satreskrim Polres Kerinci dalam mengumpulkan barang bukti tindak pidana pornografi. Kedua, Strategi Penyidik Satreskrim Polres Kerinci Dalam Mengatasi Kendala Mengumpulkan Alat Bukti Tindak Pidana Pornografi Melalui Elektronik adalah melakukan pemeriksaan digital forensik pada barang digital yang memiliki memory sebagai tempat penyimpanan data elektronik. Pengamatan dilakukan untuk mengetahui kondisi barang bukti elektronik (ON atau OFF). Dilanjutkan
\end{abstract}


dengan apakah barang bukti elektronik tersebut terhubung dengan jaringan. Guna mencegah hilangnya barang bukti maka dilakukan dokumnetasi bukti digital dengan cara Posisi awal suatu barang bukti harus dilakukan pengambilan foto. Foto awal sangat berrguna untuk menentukan jenis data dan informasi yang akan dicari pada barang bukti elektronik. Semua tindakan dalam proses penyitaan harus dituangkan dalam Berita acara penyitaan. Penyidik harus memperhatikan agar tidak membiarkan pelaku/tersangka menyentuh bukti elektronik setelah penyidik melakukan penggrebekan (satu tombol dapat menghapus seluruh bukti digital di dalam barang bukti).

Kata Kunci: Penyidikan, Media Elektronik, Pornografi, Alat Bukti

\section{PENDAHULUAN}

Pada Konsiderans Undang-Undang Nomor 11 Tahun 2008 tentang Informasi dan Transaksi Elektronik.Globalisasi teknologi tersebut menempatkan masyarakat Indonesia sebagai bagian dari masyarakat dunia pengguna teknologi komunikasi dan informasi. Globalisasi teknologi informasi juga telah merekayasa kehidupan masyarakat Indonesia ke era cyber dengan sarana internet yang menghadirkan cyberspace dengan realitas virtualnya menawarkan kepada masyarakat berbagai harapan dan kemudahan. Teknologi informasi dan komunikasi saat ini sedang mengarah kepada konvergensi yang memudahkan kegiatan manusia sebagai pencipta, pengembang dan pengguna teknologi itu sendiri. Salah satunya dapat dilihat dari perkembangan media internet yang sangat pesat. Internet sebagai suatu media dan komunikasi elektronik telah banyak di manfaatkan untuk berbagai kegiatan, antara lain untuk menjelajah (browsing,surfing), mencari berita, saling mengirim pesan melalui email, dan perdagangan. Kegiatan perdagangan dengan memanfaatkan media internet ini dikenal dengan istilah electronic commerce, atau disingkat e-commerce. ${ }^{1}$

Kemajuan dibidang ilmu pengetahuan dan teknologi telekomunikasi dan informatika juga turut mendukung perluasan ruang gerak transaksi barang dan/atau jasa hingga melintasi batas batas wilayah suatu negara. Teknologi informasi dan media elektronika dinilai sebagi simbol pelopor, yang akan mengintegrasikan seluruh sistem dunia, baik dalam aspek sosial budaya, ekonomi dan keuangan. Dari sistem-sistem kecil lokal dan nasional, proses globalisasi dalam tahun-tahun terakhir bergerakcepat, bahkan terlalu cepat menuju suatu sistem global. $^{2}$

Proses globalisasi teknologi komunikasi dan informasi tersebut melahirkan suatu fenomena yang mengubah model komunikasi tradisional dan konvensional dengan melahirkan kenyataan dalam dunia maya (virtual reality) yang dikenal sekarang ini dengan internet. Internet berkembang demikian pesat sebagai kultur masyarakat modern, dikatakan sebagai kultur karena melalui internet berbagai aktifitas masyarakat cyber seperti berpikir, berkreasi, dan bertindak dapat diekspresikan di dalamnya, kapanpun dan dimanapun. Kehadirannya telah membentuk dunia tersendiri yang dikenal dengan dunia maya (cyberspace) atau dunia semu yaitu sebuah dunia komunikasi berbasis komputer yang menawarkan realitas yang baru berbentuk virtual (tidak langsung dan tidak nyata). ${ }^{3}$ Dunia virtual tidak mengenal dimensi waktu, ruang dan tempat, yang secara realitas menunjukkan hal yang tidak atau belum nyata.

\footnotetext{
${ }^{1}$ Ahmad M Ramli, Cyber Law dan HAKI dalam Sistem Hukum Indonesia, Refika Aditama, Bandung, 2004, hlm. 1 .

2 Didik J Rachbini, Mitos dan Implikasi Globalisasi: Catatan Untuk Bidang Ekonomi dan Keuangan, Yayasan Obor, Jakarta, 2001, hlm. 2.

3 Agus Rahardjo, Cybercrime Pemahaman dan Upaya Pencegahan Kejahatan Berteknologi, Citra Aditya Bakti, Bandung, 2002, hlm. 20.
} 
Akan tetapi di balik itu, timbul persoalan berupa kejahatan yang dinamakan cybercrime, kejahatan ini juga tidak mengenal batas wilayah (borderless) serta waktu kejadian karena korban dan pelaku sering berada di negara yang berbeda. Barda Nawawi Arief mengemukakan cybercrime merupakan salah satu bentuk atau dimensi barudari kejahatan masa kini yang mendapat perhatian masyarakat luas di dunia internasional, juga merupakan salah satu sisi gelap dari kemajuan teknologi yang mempunyai dampak negatif yang sangat luas bagi seluruh kehidupan modern saat ini. ${ }^{4}$

Kesulitan untuk menemukan alat bukti yang digunakan dalam melakukan tindak pidana melalui eletronik, karena alat yang digunakan adalah komputer, sehingga bukti yang akan mengarahkan suatu peristiwa pidana adalah berupa data-data yang ada di dalam komputer itu sendiri (hard disk/floopy disk) atau yang merupakan hasil cetakan (print out), atau dalam bentuk lain berupa jejak (path) dari suatu aktivitas pengguna komputer. ${ }^{5}$ Sehingga dibutuhkan pendekatan teknis karena bukti-bukti yang ditemukan berupa bukti elektronik yang memiliki kekuatan pembuktian, maka diperlukan keterangan seorang ahli agar dapat diterima di persidangan.

Permasalahan yang dibahas adalah kendala yang dihadapi penyidik Satreskrim Polres Kerinci dalam mengumpulkan alat bukti tindak pidana pornografi melalui elektronik.

\section{METODE PENELITIAN}

Spesifikasi penelitian adalah deskriptif analitis, dengan metode pendekatan yuridis normative didukung oleh yuridis empiris. Jenis data yang digunakan adalah data sekunder dan data primer. Data sekunder diperoleh dari studi dokumen, data primer diperoleh dengan cara wawancara. Data yang diperoleh kemudian dianalisa secara kualitatif.

\section{PEMBAHASAN}

\section{A. Kendala Yang Dihadapi Penyidik Satreskrim Polres Kerinci Dalam Mengumpulkan Alat Bukti Tindak Pidana Pornografi Melalui Elektronik}

Pengumpulan alat bukti tindak pidana pornografi melalui media sosial, Satreskrim Polres Kerinci menghadapi berbagai macam kendala, diantaranya terdiri dari kendala teknis internal dan kendala teknis eksternal. Kendala teknis Internal ini diantarnya seperti kurangnya pemahaman dan penguasaan penyidik di bidang teknologi informasi, sebagian besar personil penyidik Satreskrim Polres Kerinci masih belum menguasai Teknologi Informasi dan belum adanya sosialisasi penggunaan media sosial di Polres Kerinci. Mengingat sangat pentingnya penunjang sumber daya manusia untuk menunjang kelancaran suatu proses penyelidikan, penyidikan, serta proses penangkapan.

Menurut keterangan penyidik hanya beberapa personil dan tidak banyak penyidik di Satreskrim Polres Kerinci yang memahami bidang teknologi informasi, hal ini kurang seimbang dengan adanya kasus yang ada, seiring begitu maraknya tindak pidana Pornografi melalui internet yang masih bisa terjadi kapan saja di dalam masyarakat dan masih banyaknya kasus Pornografi melalui internet yang masih belum terungkap atau hentinya tenaga lidik dikarenakan kurangnya tenaga ahli di Kantor Polisi Resort Kerinci, sehingga perlu dipikirkan oleh pemerintah untuk memberikan pelatihan TI kepada aparat

\footnotetext{
${ }^{4}$ Barda Nawawi Arief, Tindak Pidana Mayantara, Perkembangan Kajian Cybercrime di Indonesia, Raja Grafindo Persada, Jakarta, 2006, hlm. 26.

${ }^{5}$ Edmon Makarim, Kompilasi Hukum Telematika, Jakarta, PT. Raja Grafindo Persada, Jakarta, 2004, hlm. 385
} 
kepolisian baik di setiap Polres maupun Polsek khusus Cyber Crime.

Kendala teknis internal lainnya yaitu terlalu banyaknya beban pekerjaan penyidik yang ada di unit cyber crime satreskrim polres kerinci. Penyidik tidak terfokus untuk menangani cybercrime khususnya Pornografi konsentrasi mereka terpecah kepada perkaraperkara yang sudah ada terkadang menyimpang jauh contohnya penggelapan, penipuan. Di dalam Satreskrim Polres Kerinci sudah dibagi-bagi spesifikasinya namun karena laporan polisi dari masyarakat di Satreskrim Polres Kerinci beraneka ragam dan banyak di luar cyber crime sehingga ideal di dalam penanganan kepolisian terlampaui dan ini berimplikasi terhadap kecepatan penanganan perkara baik yang dilaporkan oleh masyarakat maupun yang ditemukan oleh penyidik itu sendiri.

Kemudian kurangnya fasilitas yang modern dalam pencarian barang bukti juga menjadi kendala teknis internal Satreskrim Polres Kerinci dalam mengumpulkan barang bukti tindak pidana pornografi. Pemahaman Penyidik yang masih belum memahami tindak pidana umum dengan cyber crime bagaimana secara teknis memperlakukan baik saksi maupun barang bukti, karena cyber crime diolah dan diperlakukan secara khusus tidak seperti barang bukti tindak pidana yang lain. Contohnya software ketika penyidik mematikan dan mencabut laptop atau komputer yang digunakan menjadikan hilang barang buktinya dan bagaimana memecahkan kode-kode yang sudah di setting sedemikian rupa oleh pelaku sehingga ketika penyidik mencoba membuka kode-kode tersebut sudah berubah data yang ditampilkan. Seperti pada kasus yang diuraikan pada Bab sebelum ini.

Proses pelacakan dan penyelidikan ini dilakukan secara manual dengan cara menelusuri data-data yang ada, tidak terdapat alat-alat yang canggih yang digunakan oleh penyidik di Satreskrim Polres Kerinci, alat-alat yang canggih hanya terdapat di Markas Besar Kepolisian Republik Indonesia (MABES POLRI) dan Kepolisian Daerah Metropolitan Jakarta Raya (POLDA METRO JAYA). Namun demikian penyidik tetap diperbolehkan menggunakan alat canggih tersebut pada saat keadaan yang mendesak dan proses perijinannya pun sangat diperhitungkan dikarenakan mengingat alat canggih tersebut mencapai milyaran rupiah, alat tersebut bisa melacak arah sinyal, sampai sejauh ini semua kasus penipuan melalui internet cara penanganannya dilakukan secara manual dengan melakukan kerjasama dengan instansi lain yang terkait serta menelusuri situs-situs web yang terkait dengan Pornografi melalui internet dan belum pernah meminjam alat canggih tersebut. Jadi kepolisian dituntut untuk harus benar-benar mencermati dan teliti dalam melakukan pelacakan tersangka sehingga tidak salah sasaran pada waktu penangkapan dan pengumpulan barang bukti.

Disamping itu, dalam mengumpulkan alat bukti tindak pidana pornografi, penyidik juga menghadapi berbagai kendala teknis eksternal, berupa: Sulitnya memperoleh alat bukti yang terdapat di dalam kasus Pornografi melalui internet mengakibatkan proses penyelidikan dan penyidikan sering terhenti, karena ini termasuk kasus Cyber Crime maka alat bukti untuk melakukan proses penyelidikan hanya berupa informasi elektronik dan dokumen elektronik, karena Tempat Kejadian Perkara (TKP) terjadi di dalam internet maka penyidik menelusuri dan mengamati dengan menggunakan internet serta jika diperlukan penyidik mengadakan kerjasama dengan instansi lain yang terkait dalam Pornografi melalui internet, jika di dalam kasus ini ditemukan tidak cukup bukti maka proses penyelidikan dihentikan. 
Menurut Penyidik pada Satreskrim Polres Kerinci kendala eksternal yang sering dialami di lapangan selama proses penyelidikan yaitu seperti sulit mendapatkan alamat tersangka, kendala yang paling sering terjadi dalam proses penyelidikan adalah alamat yang terdaftar pada identitas tersangka fiktif, karena pelaku dengan mudahnya membuat Akun dengan nama dan alamat palsu, untuk melakukan aksinya pelaku tidak berdiam di satu tempat, dengan menggunakan peralatan atau gadget canggih pelaku melakukan aksinya dimana saja, dan juga pelaku menghilangkan jejak dengan membuang nomor telepon pelaku sehingga tidak bisa dilacak posisinya, untuk selanjutnya alamat yang masih bisa ditelusuri dan masih bisa dicari keberadaannya maka kepolisian akan terus mencari.

Selain itu, tingginya Penguasaan Pelaku Dalam Mengoperasionalkan Teknologi Informasi. Akun-akun yang dijadikan media Pornografi yang belum terkontrol membuat Pornografi melalui internet semakin marak di masyarakat karena kemudahan akses, dibarengi dengan kemampuan pelaku tindak pidana Pornografi melalui internet yang semakin canggih dalam mengoperasionalkan Akun-akun.Dan untuk mengungkap kejahatan Pornografi melalui internet di Satreskrim Polres Kerinci harus meminta bantuan kepada Kepolisian Daerah Kerinci untuk melakukan tracking keberadaan pelaku, karena kurang lengkapnya peralatan yang menunjang di Satreskrim Polres Kerinci. Sehingga penyidik harus menunggu informasi yang diberikan kepada Polda, dan apabila Polda tidak memberikan informasi apapun maka tindak pidana Pornografi tidak bisa diungkap oleh Satreskrim Polres Kerinci sampai ketika Polda memberikan informasi keberadaan pelaku, sehingga ini berpengaruh kepada kecepatan penanganan perkara, seumpama Satreskrim Polres Kerinci memiliki sarana dan prasarana yang memadai serta peralatan yang menunjang tentu bisa mengungkap pelaku, sehingga selama ini dilakukan secara manual dan untung-untungan dalam menangkap pelaku.

\section{B. Strategi Penyidik Satreskrim Polres Kerinci Dalam Mengatasi Kendala Mengumpulkan Alat Bukti Tindak Pidana Pornografi Melalui Elektronik Oleh Penyidik}

Tindak pidana pornografi sebagai salah satuk bentuk norma, kaidah, atau hukum yang dirumuskan dalam perundang undangan pidana, baik ketentuan dalam KUHP ataupun ketentuan dalam perundang undangan di luar KUHP, sebagaimana bentuk tindak pidana pornografi/pornoaksi dan dalam perkembangannya menjadi tindak pidana pronografi/pornoaksi siber. ${ }^{6}$ Keberadaan pornografi berasal dari pornos sebagai pelanggaran kesusilaan atau cabul serta grafi sebagai tulisan, gambar, dan patung, sehingga pornografi sebagai bentuk tindak pidana dalam lingkup kesusilaan (pasal 282 dan 283 bis KUHP serta pasal 532 dan 533 KUHP); yang diikuti dengan pandangan HB $\mathrm{Jassin}^{7}$ bahwa pornografi sebagai tulisan atau gambaran dengan maksud sengaja untuk merangsang seksual; yang membuat fantasi pembaca berangan angan kearah kelamin serta menyebabkan nafsu birahi bergelora. Pornografi sebagai sesuatu yang berhubungan dengan persoalan seksual yang tidak pantas diungkapkan secara terbuka kepada umum.

Untuk mengatasi kendala-kendala tersebut Satreskrim Polres Kerinci mempunyai upaya untuk mengantisipasi terjadinya tindak pidana Pornografi melalui internet. Ada 2

\footnotetext{
${ }^{6}$ Wirjono Prodjodikoro, Tindak tindak Pidana Tertentu Di Indonesia, Eresco, Jakarta, 1980, hlm 65

${ }^{7}$ Tjita Lesmana, Pornografi Dalam Media Massa, Puspa Swara, Jakarta, 1995, hlm 70
} 
jenis upaya dilakukan penyidik yaitu upaya teknis internal adalah upaya yang dilakukan sebelum terjadinya tindak pidana dan upaya teknis eksternal adalah upaya yang dilakukan setelah tindak pidana terjadi.

Upaya yang dilakukan penyidik untuk mengatasi kendala-kendala internal yaitu dengan mengadakan pelatihan terhadap setiap anggota cyber crime di satreskrim polres kerinci. Meningkatkan kemampuan sumber daya Kepolisian dengan cara memberikan pelatihan terhadap setiap anggota agar kasus-kasus yang berhubungan dengan Cyber Crime dapat ditangani dengan maksimal. Karena di dalam menjalankan tugasnya setiap anggota Polri dituntut untuk bersikap profesional dalam menangani semua kasus mulai dari menerima laporan dari masyarakat, proses penyelidikan, proses penyidikan hingga proses pemberkasan (BAP) dan juga setiap tahunnya modus-modus Cyber Crime semakin bervariatif dan semakin canggih oleh karena itu kepolisian dituntut untuk bisa mengatasi jenis-jenis kejahatan yang bersifat canggih tersebut. Dan juga meningkatkan sarana dan prasarana serta melengkapi peralatan yang menunjang dalam proses penyelidikan dan penyidikan sehingga dapat mempermudah dalam menangani kasus yang berkaitan dengan Cyber Crime khususnya pornografi.

Adapun strategi yang dilakukan penyidik dalam memeriksa bukti elektronik adalah terlebih dahulu Penyidik harus mampu mengenali barang bukti elektronik yang berada di TKP. Pada dasarnya barang bukti elektronik yang bisa di lakukan pemeriksaan digital forensik adalah barang digital yang memiliki memory sebagai tempat penyimpanan data elektronik. Pengamatan dilakukan untuk mengetahui kondisi barang bukti elektronik (ON atau OFF). Dilanjutkan dengan apakah barang bukti elektronik tersebut terhubung dengan jaringan. Ada berapa banyak komputer/PC/Desktop yang terhubung satu dengan yang lain Pengambilan barang bukti harus sesuai dengan prosedur yang ada untuk mencegah rusaknya/ hilangnya barang bukti.

Guna mencegah hilangnya barang bukti maka dilakukan dokumnetasi bukti digital dengan cara Posisi awal suatu barang bukti harus dilakukan pengambilan foto. Foto awal sangat berrguna untuk menentukan jenis data dan informasi yang akan dicari pada barang bukti elektronik. Semua tindakan yang dilakukan terhadap barang bukti harus dilakukan pencatatan, semua tindakan dalam proses penyitaan harus dituangkan dalam Berita acara penyitaan. Pencatatan diperlukan agar kegiatan pengambilan barang bukti sesuai dengan prosedur dan tidak ada data digital yang rusak (corrupt). Pembungkusan barang bukti (dituangkan dalam BA pembungkusan barang bukti).

Penyidik harus memperhatikan agar tidak membiarkan pelaku/tersangka menyentuh komputer setelah penyidik melakukan penggrebekan (satu tombol dapat menghapus seluruh bukti digital di dalam barang bukti). Lakukan penggeledahan secara menyeluruh yang meliputi badan, tas, pakaian, celana, tempat penyimpanan, dsbnya, yang mempunyai hubungan langsung dengan tersangka. Jangan pernah nyalakan/ menghidupkan kembali barang bukti yang sudah dalam posisi mati atau dimatikan. Terhadap perkara perkara khusus, lakukan penyitaan akun media social, email dan website pelaku dengan cara merubah username dan password pelaku dan menghilangkan link email serta dituangkan di dalam BA penyitaan bukti digital. Terhadap perkara perkara khusus, lakukan pengecekan IP Publik yang digunakan oleh perangkat kompuet atau mobile jika terhubung dengan jaringan internet, salah satu caranya adalah 
mengunjungi alamat http://whatismyipaddress.com/ .

Selain itu, meningkat kinerja penyidik dan mengadakan evaluasi kasus setiap selesai menangani suatu kasus juga menjadi salah satu upaya dalam menghadapi kendala dalam mengumpulkan bukti tindak pidana pornografi. Peningkatan dan evaluasi ini dimaksudkan agar semua anggota penyidik Kepolisian Resort Kerinci dapat menyadari kelemahan-kelemahan dan kekurangan-kekurangan dalam setiap kasus Pornografi agar dalam penanganan setiap kasus yang dihadapi selanjutnya setiap anggota siap menangani kasus secara maksimal, dengan evaluasi kasus ini juga dapat memahami kekurangankekurangan dari kesalahan anggota yang bekerja kurang maksimal sehingga dapat dijadikan peringatan pada setiap anggota yang lainnya agar tidak melakukan kecerobohan dalam menjalankan tugas-tugas selanjutnya dikemudian hari.

Kemudian upaya lainnya yaitu melalui pengajuan permohonan untuk penambahan sarana dan prasarana yang menunjang. Kurang lengkapnya sarana dan prasarana penunjang operasional sangatlah menghambat dalam proses penyelidikan dan penyidikan karena kasus Pornografi ini sangat membutuhkan peralatan yang lebih canggih. Oleh karena itu sudah sewajarnya pihak Polri untuk mengupdate dan upgrade sarana dan prasarana diberikan agar penanganan kasus pornografi melalui internet dapat diselesaikan dengan maksimal.

Disamping upaya penyidik untuk mengatasi kendala- kendala internal, penyidik juga memiliki upaya untuk mengatasi kendala-kendala eksternal yakni melalui cara seperti menjalin hubungan kerja sama dengan pihak-pihak yang terkait. Salah satu upaya Polri untuk mengatasi hambatan terhadap kasus Pornografi melalui internet adalah menjalin hubungan atau kerja sama dengan instansi yang berkaitan dengan Pornografi. Membangun kerja sama ini sangatlah penting karena bisa menunjang dalam pencarian barang bukti elektronik maupun mencari keberadaan tersangka.

Penyidik Satreskrim Polres Kerinci mengharapkan adanya MoU kerja sama kepada instansi- instansi yang terkait dengan Pornografi melalui internet, salah satunya dengan penyedia layanan internet, dan membangun kerja sama dengan kementerian telekomunikasi dan informasi serta menjalin hubungan dengan universitas dan institut yang berada di Sumatera Barat untuk keperluan adanya saksi ahli sesuai dengan kebutuhan penyidikan, penyelidikan, dan bukti lain yang diperlukan.

\section{KESIMPULAN}

Lembaga terkait baik eksekutif maupun legislatif mengeluarkan aturan pelaksana atau melakukan perevisian terhadap Undang-Undang No. 11 Tahun 2008 Tentang Informasi dan Transaksi Elektronik terkait memperjelas jenisjenis alat bukti elektronik terutama mengenai penjelasan jenis-jenis alat bukti elektronik.

\section{DAFTAR PUSTAKA}

Ahmad M Ramli, Cyber Law dan HAKI dalam Sistem Hukum Indonesia, Refika Aditama, Bandung, 2004

Didik J Rachbini, Mitos dan Implikasi Globalisasi: Catatan Untuk Bidang Ekonomi dan Keuangan, Yayasan Obor, Jakarta, 2001 
Agus Rahardjo, Cybercrime Pemahaman dan Upaya Pencegahan Kejahatan Berteknologi, Citra Aditya Bakti, Bandung, 2002

Barda Nawawi Arief, Tindak Pidana Mayantara, Perkembangan Kajian Cybercrime di Indonesia, Raja Grafindo Persada, Jakarta, 2006

Edmon Makarim, Kompilasi Hukum Telematika, Jakarta, PT. Raja Grafindo Persada, Jakarta, 2004

Wirjono Prodjodikoro, Tindak tindak Pidana Tertentu Di Indonesia, Eresco, Jakarta, 1980

Tjita Lesmana, Pornografi Dalam Media Massa, Puspa Swara, Jakarta, 1995 